\title{
Decrease in calmodulin concentrations during heparin-induced capacitation in bovine spermatozoa
}

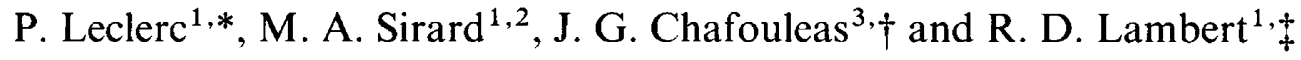 \\ 'Ontogénie et Reproduction and ${ }^{3}$ MRC Group in Molecular Endocrinology Centre de recherche du \\ CHUL 2705 Boulevard Laurier, Ste-Foy, Québec, GIV 4G2, Canada; and ${ }^{2}$ Département de \\ Zootechnie Université Laval Québec, Québec GIK 7 P4 Canada
}

\begin{abstract}
Summary. Concentrations of the intracellular $\mathrm{Ca}^{2+}$-mediator calmodulin $(\mathrm{CaM})$, were measured by radioimmunoassay during heparin-induced capacitation of bull spermatozoa. Heparin reduced sperm CaM concentrations in a dose-dependent manner corresponding with an increase in in-vitro fertilization rates. Such reductions were observed after heparin treatment for 4-6h, which is in agreement with the length of the capacitation period in bulls and was concomitant with an increase in CaM concentration in the incubation medium, suggesting translocation of $\mathrm{CaM}$ from the spermatozoa to the surrounding milieu. This CaM translocation was inhibited partly by the protease inhibitor benzamidine, suggesting a role for the sperm protease in this process.
\end{abstract}

Keywords: calmodulin; spermatozoa; capacitation; heparin; cow

\section{Introduction}

Sperm capacitation, which is known to be a prerequisite for successful fertilization (Chang, 1951), is essential for the physiological acrosome reaction (Florman \& First, 1988). The biochemical events which occur during capacitation are unclear; the importance of extracellular $\mathrm{Ca}^{2+}$ was observed years ago (Yanagimachi \& Usui, 1974). Sperm capacitation is characterized by an increase in intracellular $\mathrm{Ca}^{2+}$ (Singh et al., 1978), but the specific effects of $\mathrm{Ca}^{2+}$ are unresolved. Sperm cells contain large amounts of calmodulin (CaM) (Jones et al., 1980), an important $\mathrm{Ca}^{2+}$ mediator. CaM is highly conserved among different species and is known to regulate a large number of enzymes in various cell types (for review, see Cheung, 1980; Means et al., 1982). Although CaM is involved in sperm motility (Brokaw \& Nagayama, 1985), its location in the acrosomal region (Jones et al., 1980; Moore \& Dedman, 1984; Weinman et al., 1986) suggests a role in the capacitation or acrosome reaction process. CaM-binding proteins occur in bull spermatozoa (Noland et al., 1985; Olson et al., 1985; Leclerc et al., 1989), and the treatment of spermatozoa with heparin, which is known to induce capacitation (Parrish et al., 1988), reduces binding of CaM to specific binding proteins (Leclerc et al., 1989, 1990). This reduction is positively correlated with an increase in in-vitro fertilization (Leclerc et al., 1990). A decrease in CaM concentrations has been observed during the treatment of squirrel monkey spermatozoa with cyclic adenosine monophosphate AMP analogues (Chan \& Dukelow, 1985). The present study evaluated the effect of heparin treatment on CaM concentrations in bull spermatozoa.

\footnotetext{
*Present address: Department of Obstetrics \& Gynecology, University of Pennsylvania School of Medicine, Philadelphia, PA 19104-6080, USA.

tPresent address: Dept. of Biochemistry, Bio-Mega Inc., Laval, Québec, Canada.
}

${ }_{+}$Reprints requests. 


\section{Materials and Methods}

Sperm culture. Frozen bull spermatozoa were donated generously by the Centre d'Insemination Artificielle du Québec (CIAQ Inc., St-Hyacinthe, Québec, Canada). Different bulls were used individually in some experiments, while a pool of semen from five bulls was used in others, as variability has been reported in the response of bulls to heparin in in-vitro fertilization experiments (Hillery et al., 1990). In each experiment, the straws were thawed for $30 \mathrm{~s}$ in a water bath at $35^{\circ} \mathrm{C}$ and the spermatozoa were washed twice in Sp-TALP medium (Parrish et al., 1988) supplemented with $6 \mathrm{mg}$ bovine serum albumin/ml (BSA; fatty-acid-free, Sigma, St Louis, MO, USA). Finally, the sperm cells were resuspended at $10 \times 10^{6}$ cells $/ \mathrm{ml}$ in the same medium and incubated for up to $6 \mathrm{~h}$ in a humidified incubator $\left(39^{\circ} \mathrm{C}, 5 \% \mathrm{CO}_{2}\right.$ in air). Heparin (Sigma) and benzamidine (Sigma) were added as indicated in different experiments. The incubation of spermatozoa was performed in polystyrene tubes in a final volume of $1 \mathrm{ml}$, and the initial motility ranged from 58 to $72 \%$. Samples of these sperm suspensions were taken for CaM determination and, in some experiments, for in-vitro fertilization.

Calmodulin determination. The sperm suspensions were centrifuged $\left(520 \mathrm{~g}, 4^{\circ} \mathrm{C}\right)$ and the incubation medium (supernatant) was removed and heated for $5 \mathrm{~min}$ at $95^{\circ} \mathrm{C}$ and then cooled in an ice bath. CaM was assayed using a radioimmunoassay kit (Amersham, Oakville, Ontario, Canada). The pellet (spermatozoa) obtained after centrifugation was resuspended to the initial volume in homogenization buffer $(125 \mathrm{~mm}$ sodium borate at $\mathrm{pH} 8.4,1 \mathrm{~mm}$ ethyleneglycol bis ( $\beta$-aminoethyl ether) $N, N, N^{\prime}, N^{\prime}$-tetra-acetic acid (EGTA), $92 \mathrm{mM}-\mathrm{NaCl}$ ) before being exposed to the heat treatment as for the incubation medium. The CaM extraction from the sperm cells was facilitated by two sonication periods of $15 \mathrm{~s}$ each. The spermatozoa were centrifuged again for $10 \mathrm{~min}\left(12000 \mathrm{~g}, 4^{\circ} \mathrm{C}\right)$ and $\mathrm{CaM}$ was assayed in this last supernatant as described for the incubation medium.

In-vitro fertilization. In-vitro fertilization using in-vitro matured oocytes (as described by Sirard et al., 1988) was performed to evaluate the capacitation state of the treated spermatozoa. The ovaries, collected at a slaughterhouse, were transported to the laboratory in saline $\left(0.9 \% \mathrm{w} / \mathrm{v} \mathrm{NaCl}, 34-37^{\circ} \mathrm{C}\right)$ within $1.5 \mathrm{~h}$. Intact cumulus $\cdots$ oocyte complexes were washed three times and allowed to mature for $24 \mathrm{~h}$ at $39^{\circ} \mathrm{C}\left(5 \% \mathrm{CO}_{2}\right.$ in air) in TCM-199 (Earle's salts, Gibco, Mississauga, Ontario, Canada) supplemented with 10\% fetal bovine serum (FBS; Flow laboratories, Mississauga, Ontario, Canada), 0.2mm pyruvate (Sigma, St Louis, MO, USA), $1 \mu \mathrm{g}$ oestradiol-17ß/ml (Sigma, St Louis, MO, USA), $0.5 \mu \mathrm{g}$ ovine follicle-stimulating hormone ( $\mathrm{FSH} / \mathrm{ml}$ and $5 \mu \mathrm{g}$ bovine luteinizing hormone $(\mathrm{LH}) / \mathrm{ml}$. The hormones FSH and LH were provided by the National Institute of Diabetes, Digestive and Kidney Diseases and the National Hormone and Pituitary Program. The matured oocytes were next washed three times in Lb-TALP (Parrish et al., 1988) and finally added to the drops of fertilization medium (Fert-TALP, Parrish et al., 1988) under mineral oil (Aldrich, Milwaukee, WI, USA). The spermatozoa, treated as described above, were added to the final concentration of $1 \times 10^{6} \mathrm{cells} / \mathrm{ml}$ to the oocytes. After co-incubation for $16 \mathrm{~h}$, the oocytes were denuded of the attached cumulus cells, fixed in ethanol:acetic acid (3:1) and stained with $1 \%$ orcein in $40 \%$ acetic acid. The fertilization rates were evaluated under phase-contrast microscopy at a magnification of $\times 200$. An oocyte was judged fertilized when two pronuclei were seen within the cytoplasm.

Acrosome reaction. The assessment of acrosome integrity before, and after, the heparin treatment and after the first centrifugation for the CaM assay was measured using the Naphthol Yellow S/Erythrosin B procedure (Bryan \& Akruk, 1977) modified by Lenz et al. (1983). This staining procedure correlates with observations using electron microscopy (Lenz et al., 1983; McBride et al., 1990) regarding the acrosomal status. A minimum of 100 spermatozoa were evaluated per slide.

Statistical analysis. According to the experiment, the data were statistically analysed using Student's $t$ test, the paired $t$ test, Fisher's protected least-significant difference, or analysis of variance (ANOVA) applied to a randomized block design.

\section{Results}

\section{Effect of $\mathrm{Ca}^{2+}$, glucose and heparin}

This set of experiments evaluated the effect of $6 \mathrm{~h}$ of incubation in the presence or absence of $\mathrm{Ca}^{2+}(2 \mathrm{~mm})$, glucose (5mM) and/or heparin $(2 \mu \mathrm{g} / \mathrm{ml})$ on sperm CaM concentrations. Four bulls were used in a $2 \times 2 \times 2$ factorial experiment. When the spermatozoa were incubated for $6 \mathrm{~h}$ in the presence of heparin, CaM concentrations assayed in the sperm cells were lower than in the controls $(P<0.05)$ except when glucose was present in the $\mathrm{Ca}^{2+}$-free medium (Fig. la). The reduction in 
CaM concentrations was concomitant to an increase $(P<0.05)$ in the CaM measured in the incubation medium (Fig. 1b). Such an increase was also observed when the spermatozoa were incubated in the $\mathrm{Ca}^{2+}$-free and heparin-free medium which contained glucose. None of these variations in cellular and extracellular CaM concentrations affected the total assayed CaM, obtained by the addition of the concentrations measured in the spermatozoa and in the incubation medium (Fig. 1c). A $2 \times 2 \times 2$ factorial ANOVA applied to a randomized block design was performed on the CaM concentrations in spermatozoa and in the incubation medium after $6 \mathrm{~h}$ of treatment (Table 1). There were marked differences between bulls in cellular and extracellular CaM concentrations $\left(P=0.0001\right.$ and $P=0.0005$, respectively). Nevertheless, $\mathrm{Ca}^{2+}(P=0.025)$ and heparin $(P=$ 0.0002 ) induced an overall reduction in sperm CaM concentrations. In the incubation medium, the presence of $5 \mathrm{~mm}$ glucose inhibited $(P=0.005)$ the increase of CaM after $6 \mathrm{~h}$ of incubation, but heparin induced it $(P=0.007)$.

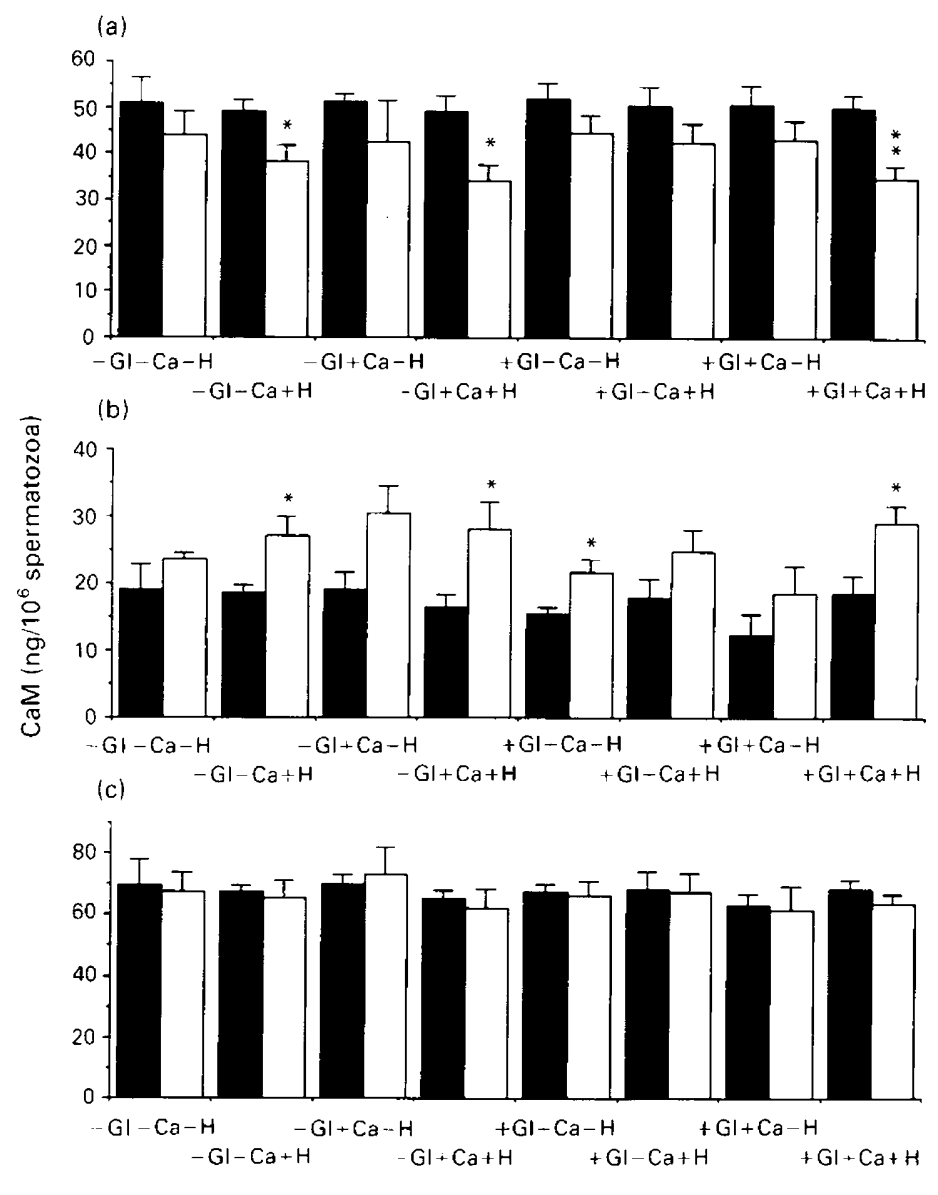

Fig. 1. Concentration of calmodulin (CaM) in (a) bovine spermatozoa, (b) incubation medium and (c) the sum in spermatozoa and incubation medium, at the beginning ( $\square$ ) or after incubation for $6 \mathrm{~h}(\square)$ with $5 \mathrm{~mm}$ glucose $(\mathrm{Gl}), 2 \mathrm{mM} \mathrm{Ca}^{2+}(\mathrm{Ca})$ and $2 \mu \mathrm{g}$ heparin/ml $(\mathrm{H})$. Four bulls were used in duplicate for that study. Data are means \pm s.e.m. Compared with the beginning of the incubation, significant differences were observed: ${ }^{*} P<0 \cdot 05,{ }^{* *} P<0 \cdot 01$, using Student's $t$ test analysis. 
Table 1. Three-factor analysis of variance applied to a randomized block design on the calmodulin concentrations in bovine sperm cells and in the incubation medium measured after $6 \mathrm{~h}$ of incubation with, or without, $5 \mathrm{~mm}$ glucose, $2 \mathrm{~mm} \mathrm{Ca} \mathrm{Ca}^{2+}$ and $2 \mu \mathrm{g}$ heparin $/ \mathrm{ml}$

\begin{tabular}{lcc}
\hline \multicolumn{3}{c}{ Significance level $(P)$} \\
\hline Source & Spermatozoa & Incubation medium \\
\hline Bulls & 0.001 & 0.0005 \\
Glucose (Gl) & NS & 0.005 \\
$\mathrm{Ca}^{2+}(\mathrm{Ca})$ & 0.025 & $\mathrm{NS}$ \\
$\mathrm{Heparin}(\mathrm{Hep})$ & 0.0002 & 0.007 \\
Gl $\times$ Ca & $\mathrm{NS}$ & $\mathrm{NS}$ \\
Gl $\times$ Hep & $\mathrm{NS}$ & 0.02 \\
$\mathrm{Ca} \times \mathrm{Hep}$ & $\mathrm{NS}$ & $\mathrm{NS}$ \\
Gl $\times \mathrm{Ca} \times \mathrm{Hep}$ & $\mathrm{NS}$ & 0.01 \\
\hline
\end{tabular}

This analysis was performed using data presented in Fig. 1 (a) and (b), each of the four bulls being considered as a specific block.

\section{Effect of benzamidine with heparin}

To evaluate whether the effect of heparin was mediated by sperm protease, the protease inhibitor benzamidine $(50 \mathrm{~mm})$ was added to the heparin treatment. Heparin induced a reduction in sperm CaM concentrations from 46.9 to $32.5 \mathrm{ng} / 10^{6}$ cells $(P<0.05$, Fig. $2 \mathrm{a})$. When benzamidine was added to the heparin treatment, a smaller reduction was observed and the CaM concentrations in the spermatozoa after $6 \mathrm{~h}$ of incubation were higher than in the absence of benzamidine $(40 \cdot 2 \mathrm{ng} /$ $10^{6}$ cells, $P=0.03$ ). An increase in the CaM concentrations in the incubation medium was observed at the end of the 6-h heparin treatment $\left(9.7\right.$ to $34.0 \mathrm{ng} / 10^{6}$ cells $\left.P<0.05\right)$. When benzamidine was present, the $\mathrm{CaM}$ concentrations measured in the incubation medium increased from $7 \cdot 3$ to $23.4 \mathrm{ng} / 10^{6}$ cells $(P<0.05)$. After $6 \mathrm{~h}$ of incubation, the CaM concentrations were lower $(P=0 \cdot 0002)$ when benzamidine was added to heparin (Fig. 2b).

\section{Dose-response to heparin}

When the sperm cells were incubated for $6 \mathrm{~h}$ in the absence of heparin, a significant reduction in sperm CaM concentrations was observed ( 74.6 vs. $64.8 \mathrm{ng} / 10^{6}$ cells, $P<0.01$ ). Increasing the concentration of heparin in the medium induced a progressive reduction in sperm $\mathrm{CaM}$ concentrations and a progressive increase in the $\mathrm{CaM}$ concentrations assayed in the incubation medium (Fig. 3a). No difference was detected in the total CaM concentrations before and after the $6 \mathrm{~h}$ incubation in the presence or absence of heparin (Fig. 3b); $77.3 \%$ of the assayed CaM was present in the spermatozoa before the incubation and was reduced to $68.0 \%(P<0.05)$ after $6 \mathrm{~h}$ of incubation without heparin (Fig. 3 b). This sperm CaM ratio gradually decreased to $50.5 \%$ as the heparin concentration increased to $10 \mu \mathrm{g} / \mathrm{ml}$.

In-vitro fertilization of bovine oocytes was performed to assess the capacitation state of the heparin-treated spermatozoa. At the end of the incubation, a sample of the spermatozoa treated with increasing concentrations of heparin was used to fertilize the oocytes. The in-vitro fertilization rates increased from 2.0 to $40.2 \%(P<0.01)$, when the heparin concentration was increased from 0 to $10 \mu \mathrm{g} / \mathrm{ml}$ in the treated spermatozoa (Fig. 4 ).

\section{Time dependence of the effect of heparin}

The changes in the sperm CaM concentrations were dependent on the length of the incubation period in the presence of heparin (Fig. 5a). After incubation for 4 or $6 \mathrm{~h}$ in the presence of heparin 


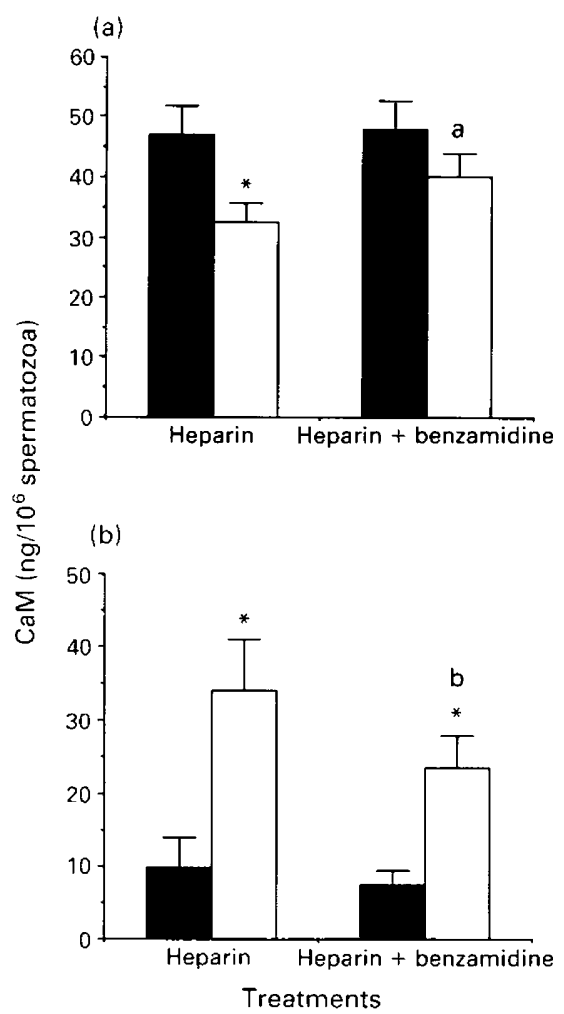

Fig. 2. Concentration of calmodulin (CaM) in (a) bovine spermatozoa and (b) incubation medium, at the beginning ( $\boldsymbol{\square})$ or after incubation for $6 \mathrm{~h}(\square)$ with $2 \mu \mathrm{g}$ heparin $/ \mathrm{ml}$ or with heparin and $50 \mathrm{~mm}$ benzamidine. The spermatozoa were incubated in the presence of $2 \mathrm{~mm} \mathrm{Ca}{ }^{2+}$ and in the absence of glucose. Data are expressed as in Fig. 1 using the same bulls. Compared with the beginning of the incubation, ${ }^{*} P<0.05$ using Student's $t$ test analysis. Compared with the concentrations observed after treatment with heparin alone, ${ }^{\mathrm{a}} P=0.03$ and ${ }^{\mathrm{b}} P=0.0002$ using an ANOVA applied to a randomized block design, each bull considered as a block.

$(5 \mu \mathrm{g} / \mathrm{ml})$, the $\mathrm{CaM}$ concentration was reduced from 74.0 at the beginning of the incubation to $56 \cdot 8$ $(P<0.05)$ and $51.8(P<0.01) \mathrm{ng} / 10^{6}$ cells, respectively, significantly less $(P<0.005)$ than when heparin was absent from the incubation medium $\left(64.5 \mathrm{ng} \mathrm{CaM} / 10^{6}\right.$ cells). Again, the CaM concentrations in the incubation medium rose from 11.8 to $24.2(P<0.005)$ and $24.8 \mathrm{ng} / 10^{6}$ cells $(P<0.005)$ during the 4 or $6 \mathrm{~h}$ incubation with $5 \mu \mathrm{g} / \mathrm{ml}$ heparin, respectively. After treatment for $6 \mathrm{~h}$, this is higher than the $19.3 \mathrm{ng} / 10^{6}$ cells $(P<0.05)$ assayed in the absence of heparin. The proportion of sperm $\mathrm{CaM}$ decreased as the incubation period with heparin lengthened. At the beginning, $86 \cdot 1 \%$ of the assayed CaM was found in the spermatozoa; this proportion fell to 76.4 $(P<0.05), 70.2(P<0.005)$ and $67.7 \%(P<0.001)$ after 2,4 and $6 \mathrm{~h}$ of incubation, respectively, with heparin (Fig. 5b). When the spermatozoa were treated for $6 \mathrm{~h}$ in the absence of heparin, $77 \%$ of the assayed CaM remained in the sperm cells, which is significantly higher $(P<0.01)$ than for the heparin-treated spermatozoa.

\section{Effect of heparin on acrosome status}

There was no difference in the acrosome reaction rates between the cells treated for $6 \mathrm{~h}$ with $10 \mu \mathrm{g}$ heparin $/ \mathrm{ml}$ and the control $(29.6$ vs. $29.9 \%)$, but these rates are higher $(P<0.01)$ than those observed at the beginning of the incubation (17.9\%) (Table 2). The acrosome status of the spermatozoa was also evaluated after the first steps of the processing of the samples for the CaM assay, to 


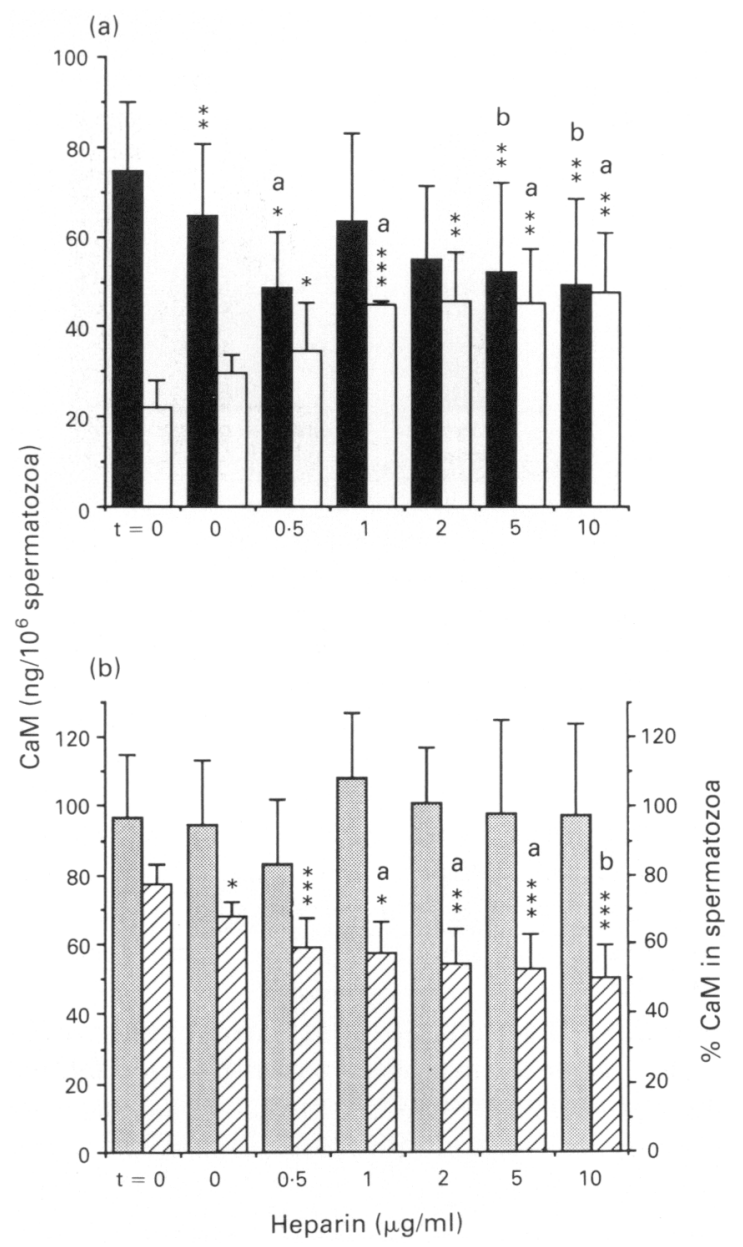

Fig. 3. Dose-dependent effect of heparin on calmodulin (CaM) concentrations in (a) bull spermatozoa ( $\square$ ) and incubation medium ( $\square$ ), (b) sum in spermatozoa and incubation medium (橉) and proportion of the total CaM present in spermatozoa ( $\mathbb{Z})$ after treatment for $6 \mathrm{~h}$. Pooled semen of five bulls was used in this study. Compared with the beginning of the treatment $(t=0)$, the significance levels are ${ }^{*} P<0.05,{ }^{* *} P<0.01,{ }^{* * *} P<0.005$. Compared with incubation for $6 \mathrm{~h}$ without heparin, the levels of significance are ${ }^{a} P<0.05$ and ${ }^{b} P<0.01$. The statistical analyses were performed using a paired $t$ test analysis.

verify whether a loss of acrosome occurred during the centrifugation $(520 \mathrm{~g})$ and the resuspension of the cells in the homogenization buffer (see Materials and Methods). Although the acrosome reaction rates (Table 2) did not differ between the spermatozoa treated with heparin and the control cells (27.1 and $30 \cdot 3 \%$, respectively), they were higher $(P<0.005$ and $P<0.001$, respectively) than in the nonincubated cells $(15 \cdot 6 \%)$.

\section{Discussion}

It has been demonstrated that heparin binds to bull spermatozoa in a ligand-receptor manner (Handrow et al., 1984) and induces capacitation (Parrish et al., 1988) which is related to net $\mathrm{Ca}^{2+}$ uptake (Handrow et al., 1989). These two effects of heparin are inhibited, or at least slowed, by the presence of glucose (Handrow et al., 1989; Parrish et al., 1989). It has also been reported that, 


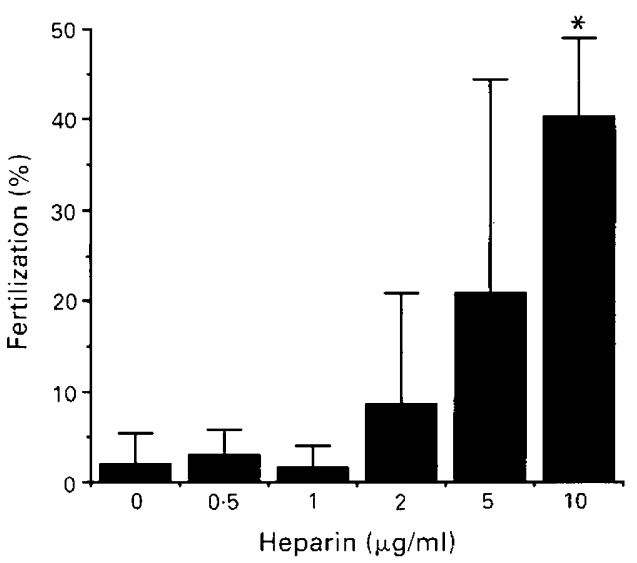

Fig. 4. In-vitro fertilization of oocytes coincubated for $16 \mathrm{~h}$ with spermatozoa previously treated for $6 \mathrm{~h}$ with different concentrations of heparin. Pooled semen of five bulls was used; calmodulin concentrations in the spermatozoa and incubation medium of these samples are shown in Fig. 3. Compared with the fertilization rates obtained when the spermatozoa were incubated without heparin, the level of significance is ${ }^{*} P<0.01$ using the Student's $t$ test analysis.

during capacitation, heparin induces changes in CaM-binding properties of specific sperm proteins (Leclerc et al., 1989, 1990). The present study shows that heparin induces a reduction in sperm $\mathrm{CaM}$ concentrations during capacitation. Such a decrease seems to be related to capacitation, since this effect is affected by the presence of $5 \mathrm{~mm}$ glucose (Fig. 1a, b; Table 1), known to inhibit sperm capacitation (Parrish et al., 1989).

The decrease in sperm CaM concentrations during in-vitro capacitation observed in this study is in agreement with the results reported in squirrel monkey (Chan \& Dukelow, 1985). The reduction in sperm CaM concentrations, added to the reduction in the CaM-binding properties of specific sperm proteins (Leclerc et al., 1989, 1990) seems to emphasize that CaM does play a primary role in sperm capacitation probably by inhibiting it. Indeed, the increase in intracellular $\mathrm{Ca}^{2+}$ is essential to capacitation (Singh et al., 1978) and $\mathrm{CaM}$ is known to be a major intracellular $\mathrm{Ca}^{2+}$ mediator. CaM has already been reported (Cohen et al., 1986) to inhibit $\mathrm{Ca}^{2+}$-dependent enzymes in a manner similar to $\mathrm{Ca}^{2+}$ chelators such as EGTA. From another perspective, CaM could help to maintain low intracellular $\mathrm{Ca}^{2+}$ by acting on $\mathrm{Ca}^{2+}$-ATPase (Hinds et al., 1978). This enzyme is present in bull sperm head membranes (Breitbart et al., 1984) and is known to facilitate export of $\mathrm{Ca}^{2+}$ out of the cytoplasm. A decrease in intracellular CaM concentrations during capacitation could therefore reduce the activity of $\mathrm{C} \mathrm{Ca}^{2+}$-ATPase and allow some increase in intracellular $\mathrm{Ca}^{2+}$. This would be in agreement with the results of Roldan \& Fleming (1989), who suggested a possible role of $\mathrm{Ca}^{2+}$-ATPase during capacitation.

The decrease in sperm CaM can be explained in different ways. First, CaM could be degraded by sperm proteases such as acrosin. The reduction in the sperm CaM concentrations reported in this paper appears to agree with the possibility of proteolysis of CaM by acrosin or other proteases since the reduction in sperm CaM is partly inhibited by benzamidine. In bull spermatozoa, benzamidine is an inhibitor of both the conversion of proacrosin to acrosin and the acrosin activity (Zalher \& Polakoski, 1977). However, the reduction of CaM in the sperm cells is associated with its increase in the extracellular milieu resulting in an unchanged total concentration of $\mathrm{CaM}$ during the treatments. According to these results, we suggest that $\mathrm{CaM}$ is released from the spermatozoa to the extracellular medium during the heparin treatment and that this release can be facilitated by the action of proteases, since benzamidine partly inhibited the heparin effect (Fig. 2a, b).

The induction of the acrosome reaction could also reduce the sperm CaM concentration since the presence of CaM has been observed in the acrosomal content. It has been demonstrated that 


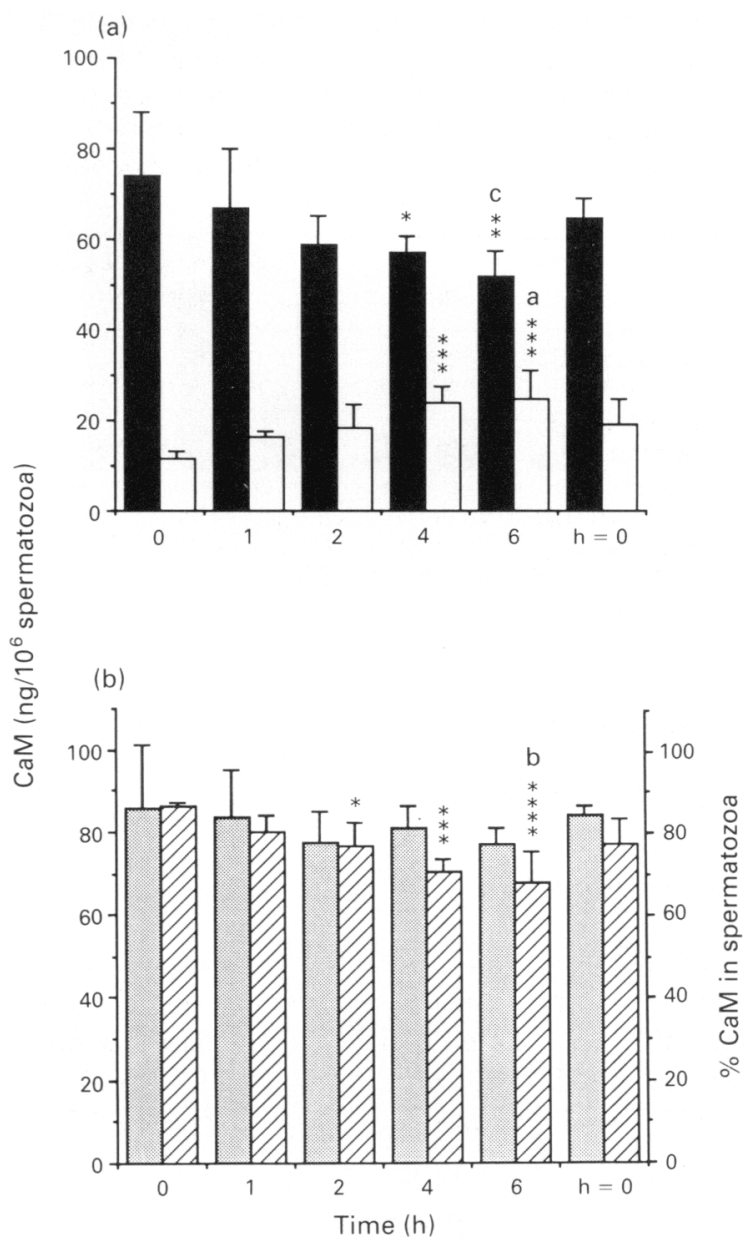

Fig. 5. Time-dependent effect of treatment of bovine spermatozoa with $5 \mu \mathrm{g}$ heparin $/ \mathrm{ml}$ on (a) calmodulin $(\mathrm{CaM})$ concentrations in bull spermatozoa $(\boldsymbol{\square})$ and incubation medium $(\square)$ and (b) sum in the spermatozoa and incubation medium (D) and the proportion of CaM in spermatozoa $(\because)$. Pooled semen of five bulls was used. Compared with the beginning of the incubation, $* * *, * * *, * * * *$ are significantly different at the $P$ values $<0.05,0.01,0.005$ and $0 \cdot 001$, respectively, using the Fisher protected least-significant difference analysis. Compared with spermatozoa incubated for $6 \mathrm{~h}$ without heparin $(h=0),{ }^{\mathrm{a}},{ }^{\mathrm{b}}$ and ${ }^{\mathrm{c}}$ are significantly different $(P<0.05, P<0.01$ and $P<0.005)$ as revealed by a paired $t$ test analysis.

$\mathrm{CaM}$ is also released in association with the plasma membrane and the outer acrosomal membrane during the acrosome reaction (Camatini et al., 1986). Under the experimental conditions used in this study, there was no difference in the acrosome reaction rates between the heparin-treated sperm and the control cells after a $6 \mathrm{~h}$ incubation. This is in agreement with Parrish et al. (1988), who showed that heparin is a capacitating agent, but does not induce the acrosome reaction. Moreover, following the incubation of spermatozoa, no additional loss of acrosome occurred during the processing of the samples for the CaM assay. Therefore, it is conceivable that the loss of the acrosome is responsible for the slight reduction in sperm CaM concentration when spermatozoa are incubated in the absence of heparin.

From the results presented in this paper, we suggest that a release of $\mathrm{CaM}$ from sperm cells to the incubation medium occurs during bull sperm capacitation induced by heparin and may be 
Table 2. Effect of treatment of bovine spermatozoa with $10 \mu \mathrm{g}$ heparin $/ \mathrm{ml}$ for $6 \mathrm{~h}$ on rate of acrosome reaction before and after centrifugation and resuspension in homogenization buffer during the processing of spermatozoa for the calmodulin assay

\begin{tabular}{lcc}
\hline & Noncentrifuged & $\begin{array}{c}\text { Centrifuged and } \\
\text { resuspended }\end{array}$ \\
\hline $\begin{array}{l}\text { Nonincubated } \\
\text { Incubated }\end{array}$ & $17 \cdot 9 \pm 6 \cdot 7$ & $15 \cdot 6 \pm 5 \cdot 6$ \\
$\begin{array}{l}\text { Incubated with } \\
\text { heparin }\end{array}$ & $29 \cdot 6 \pm 3 \cdot 4^{* *}$ & $30 \cdot 3 \pm 3 \cdot 7^{* * * *}$ \\
\hline
\end{tabular}

Results are expressed in $\% \pm$ S.D. acrosome reaction. Compared with the nonincubated cells, ${ }^{* *} P<0.01$, *** $P<0.005$ and ${ }^{* * * *} P<0.001$ using Student's $t$-test analysis.

facilitated by sperm protease. The decrease in the CaM concentrations in the spermatozoa could reduce the $\mathrm{Ca}^{2+}$ pump activity, resulting in increasing intracellular $\mathrm{Ca}^{2+}$. According to the chelating effect of $\mathrm{CaM}$ on $\mathrm{Ca}^{2+}$, reduction in intracellular $\mathrm{CaM}$ concentration could also help to increase intracellular $\mathrm{Ca}^{2+}$ concentration, allowing it to activate $\mathrm{Ca}^{2+}$-dependent enzymes and finally result in the capacitation of spermatozoa.

We thank F. Dô for excellent technical assistance, the Centre d'Insémination Artificielle du Québec (CIAQ Inc.) for providing frozen semen, and J. Poulin and E. Lecierc for typing the manuscript. P. Leclerc is supported by the Fonds de la Recherche en Santé du Québec (FRSQ) and by CIAQ Inc. This study was supported by the Medical Research Council of Canada (MRC) and by the Canadian Association of Animal Breeders (CAAB) project B88006R89.

\section{References}

Breitbart, H., Darshan, R. \& Rubinstein, S. (1984) Evidence for the presence of ATP-dependent calcium pump and ATPase activities in bull sperm head membranes. Biochem. biophys. Res. Commun. 122, 479484 .

Brokaw, C.J. \& Nagayama, S.M. (1985) Modulation of the asymmetry of sea urchin sperm flagellar bending by calmodulin. J. Cell. Biol. 100, 1875-1883.

Bryan, J.H.A. \& Akruk, S.R. (1977) A naphthol yellow S and erythrosin B staining procedure for use in studies of the arosome reaction of rabbit spermatozoa. Stain Technol. 52, 47-51.

Camatini, M., Anelli, G. \& Casale, A. (1986) Immunocytochemical localization of calmodulin in intact and acrosome-reacted boar sperm. Eur. J. Cell Biol. 41, 89-96.

Chan, P.J. \& Dukelow, W.R. (1985) Calmodulin level changes associated with cyclic AMP treatment in cultured squirrel monkey oocytes and sperm. Zool. Sci. 2, 219-223.

Chang, M.C. (1951) Fertilizing capacity of spermatozoa deposited into the Fallopian tubes. Nature, Lond. 168, 697--698.

Cheung, M.Y. (1980) Calmodulin plays a pivotal role in cellular regulation. Science, $N Y$ 207, 19-27.
Cohen, I., Kahn, D.R. \& Drisdel, R.C. (1986) Inhibition of platelet factor XIIla-catalysed reactions by calmodulin. Biochim. biophys. Acta 883, 265-270.

Florman, H.M. \& First, N.L. (1988) The regulation of acrosomal exocytosis. I. Sperm capacitation is required for the induction of acrosome reactions by the bovine zona pellucida in vitro. Devl Biol. 128, 453-463.

Handrow, R.R., Boehm, S.K., Lenz, R.W., Robinson, J.A. \& Ax, R.L. (1984) Specific binding of the glycosaminoglycan $\left[{ }^{3} \mathrm{H}\right]$-heparin to bull, monkey, and rabbit spermatozoa in vitro. $J$. Androl. 5, 51-63.

Handrow, R.R., First, N.L. \& Parrish, J.J. (1989) Calcium requirement and increased association with bovine sperm during capacitation by heparin. $J$. exp. Zool. 252, 174-182.

Hillery, F.L., Parrish, J.J. \& First, N.L. (1990) Bull specific effect on fertilization and embryo development in vitro. Theriogenology 33, 249. abst.

Hinds, T.R., Larsen, F.L. \& Vincenzi, F.F. (1978) Plasma membrane $\mathrm{Ca}^{2+}$ transport: stimulation by soluble proteins. Biochem. biophys. Res. Commun. 81, 455-461.

Jones, H.P., Lenz, R.W., Palevitz, B.A. \& Cormier, M.J. (1980) Calmodulin localization in mammalian 
spermatozoa. Proc. Natl Acad. Sci. USA 77, 2772-2776.

Leclerc, P., Langlais, J., Lambert, R.D., Sirard, M.A. \& Chafouleas, J.G. (1989) Effect of heparin on the expression of calmodulin-binding proteins in bull spermatozoa. J. Reprod. Fert. 85, 615-622.

Leclerc, P., Sirard, M.A., Chafouleas, J.G. \& Lambert, R.D. (1990) Decreased binding of calmodulin to bull sperm proteins during heparin-induced capacitation. Biol. Reprod. 42, 483-489.

Lenz, R.W., Ball, G.D., Lohse, J.K., First, N.L. \& Ax, R.L. (1983) Chondroitin sulfate facilitates an acrosome reaction in bovine spermatozoa as evidenced by light microscopy, electron microscopy and in-vitro fertilization. Biol. Reprod. 28, 683-690.

Means, A.R., Tash, J.S. \& Chafouleas, J.G. (1982) Physiological implications of the presence, distribution and regulation of calmodulin in eukaryotic cells. Physiol. Rev. 62, 1-38.

McBride, C.E., Fayrer-Hosken, R.A., Srivastava, P.N. \& Brackett, B.G. (1990) Evaluation of rabbit sperm acrosomal integrity and fertilizing ability by use of vital stains. Mol. Reprod. Devl. 26, 30-39.

Moore, P.M. \& Dedman, J.R. (1984) Calmodulin, a calmodulin acceptor protein, and calcimedins: unique antibody localization in hamster sperm. J. Cell. Biochem. 25, 99-107.

Noland, T.D., Van Eldik, L.J., Garbers, D.L. \& Burgess, W.H. (1985) Distribution of calmodulin and calmodulin binding proteins in membranes from bovine epididymal spermatozoa. Gamete Res. 11, 297-303.

Olson, G.E., Winfrey, V.P., Garbers, D.L. \& Noland, T.D. (1985) Isolation and characterization of a macromolecular complex associated with the outer acrosomal membrane of bovine spermatozoa. Biol. Reprod. 33, 76I-779.

Parrish, J.J., Susko-Parrish, J., Winer, M.A. \& First, N.L. (1988) Capacitation of bovine sperm by heparin. Biol. Reprod. 39, 11711180.

Parrish, J.J., Susko-Parrish, J.L. \& First, N.L. (1989) Capacitation of bovine sperm by heparin: inhibitory effect of glucose and role of intracellular $\mathrm{pH}$. Biol. Reprod. 41, 683-699.

Roldan, E.R.S. \& Fleming, A.D. (1989) Is a $\mathrm{Ca}^{2+}$. ATPase involved in $\mathrm{Ca}^{2+}$ regulation during capacitation and the acrosome reaction of guinea-pig spermatozoa? J. Reprod. Fert. 85, 297-308.

Singh, J.P., Babcock, D.F. \& Lardy, H.A. (1978) Increased calcium-ion influx is a component of capacitation of spermatozoa. Biochem. J. 172, 549-556.

Sirard, M.A., Parrish, J.J., Ware, C.B., LeibfriedRutledge, M.L. \& First, N.L. (1988) The culture of bovine oocyte to obtain developmentally competent embryo. Biol. Reprod. 39, 546-552.

Weinman, S., Ores-Carton, C., Reinteau, D. \& Puszkin, S. (1986) Immunoelectron microscopic localization of calmodulin and phospholipase $\mathrm{A}_{2}$ in spermatozoa. $J$. Histochem. Cytochem. 34, 1171-1179.

Yanagimachi, R. \& Usui, N. (1974) Calcium dependence of the acrosome reaction and activation of guinea-pig spermatozoa. Exp. Cell. Res. 89, 161-174.

Zahler, W.L. \& Polakoski, K.L. (1977) Benzamidine as an inhibitor of proacrosin activation in bull sperm. Biochim. biophys. Acta 480, 461-468.

Received 17 August 1990 